\title{
Serum Total Testosterone Levels Pre- and Post-Subinguinal Microsurgical Varicocelectomy in Men with Clinical Varicoceles
}

\author{
Charles Azuwike Odoemene \\ Alex Ekwueme Federal University Teaching Hospital, Abakaliki (AEFUTHA), Nigeria \\ Email: odoemenec@yahoo.com
}

How to cite this paper: Odoemene, C.A. (2021) Serum Total Testosterone Levels Pre- and Post-Subinguinal Microsurgical Varicocelectomy in Men with Clinical Varicoceles. Open Journal of Urology, 11, 124-136.

https://doi.org/10.4236/oju.2021.114013

Received: February 8, 2021

Accepted: April 25, 2021

Published: April 28, 2021

Copyright $\odot 2021$ by author(s) and Scientific Research Publishing Inc. This work is licensed under the Creative Commons Attribution International License (CC BY 4.0).

http://creativecommons.org/licenses/by/4.0/

\section{(c) (i) Open Access}

\begin{abstract}
Background: Varicocele is abnormal dilation and tortousity of the scrotal venous pampiniform plexus that drain blood from each testicle. Recently, it has been linked to low serum total testosterone (TT) levels by affecting the optimal functioning of the leydig cell via increasing the scrotal temperature. Varicocele repair has been found post-operatively to increase the serum levels of TT. This study looks at the pre and post-subinguinal microsurgical varicocelectomy serum TT levels in male patients with clinical varicocele. Methods: The study involved 88 male patients with clinical varicoceles who met the inclusion criteria. These patients after good history taking and physical examination had their serum TT levels measured pre varicocelectomy and 6 months postsubinguinal microsurgical varicocelectomy. The varicoceles were diagnosed by physical examination and use of scrotal color Doppler ultrasonography (US). Results: The number of patients with varicocele were 88 males. The mean age of the patients was $33.43 \pm 7.82$ years. There was isolated left varicocele in 57 (64.8\%) patients and bilateral varicocele in 27 (30.7\%) patients. Pre varicocelectomy, 61 (69.3\%) patients had serum TT of between 100 - 290 nanogram/deciliter (ng/dl) and a mean value of $241 \pm 0.91 \mathrm{ng} / \mathrm{dl}$. Post varicocelectomy $56(63.6 \%)$ patients had serum TT in the range of $300-490 \mathrm{ng} / \mathrm{dl}$ with a mean of $482 \pm 2.87 \mathrm{ng} / \mathrm{dl}$, showing a robust significant increase in the serum TT post-operatively $(\mathrm{P}<0.001)$. Conclusion: There was statistically significant improvement in the serum TT levels with 55 (79\%) patients exhibiting normalization of serum TT levels after subinguinal microsurgical varicocelectomy.
\end{abstract}

\section{Keywords}

Clinical Varicocele, Serum Total Testosterone, Doppler Color Ultrasonography, Varicocele Grade, Subinguinal Microsurgical Varicocelectomy 


\section{Introduction}

Varicocele is abnormal dilatation and tortousity of the scrotal venous pampiniform plexus that drain blood from each testicle [1] [2] [3] [4]. It is the most commonly identifiable correctable cause of male infertility [5]. Incidence of varicocele in healthy men is found to be $4.4 \%$ to $22.6 \%$ with an average of $15 \%$ [1] [4] [6] [7]. The prevalence in adolescent population and childhood mirrors that of the adult population and is $15.7 \%$ [7]. Varicocele affects $21 \%-39 \%$ of subfertile men [8]. It is found in $35 \%-50 \%$ of men presenting with primary infertility and $69 \%-81 \%$ of men presenting with secondary infertility [3] [4] [5] [6]. The left spermatic vein drains into the left renal vein in a perpendicular fashion. This drainage fashion coupled with the fact that the left spermatic vein traverses $8 \mathrm{~cm}$ - $10 \mathrm{~cm}$ longer with a greater increase in hydrostatic pressure accounts for a preponderance of varicocele on the left side by about $80 \%$ - 90\% [1] [4] [6] [9] [10]. Where there is a left sided varicocele, there is a $30 \%-50 \%$ probability it is a bilateral condition [1] [4] [10] [11]. Furthermore, an isolated right sided varicocele may be a pointer to associated situs inversus or retroperitoneal tumors necessitating further investigations [11]. For the diagnosis of clinical varicoceles, physical examination remains the gold standard [11] [12]. Varicoceles are graded according to the scale developed by Dubin and Amelar in 1970 [4] [11] [13].

Grade 1: Varicocele detectable by palpation only during the valsalva maneuver.

Grade 2: Varicocele detectable by simple palpation.

Grade 3: Varicocele visible on inspection and palpation.

A widely accepted US diagnosis of varicocele is the existence of veins larger than 2 millimeters $(\mathrm{mm})$ in diameter [11]. The pathogenic mechanisms of varicoceles which include oxidative stress, heat stress, toxin accumulation can affect adversely the function of the leydig cells of the testis responsible for $95 \%$ testosterone production in adult men [6] [14]. This study looks at serum TT in patients with clinical varicocele and also serum TT 6 months post-subinguinal microsurgical varicocelectomy with a view to finding out if there is improvement in the serum TT.

\section{Material and Method}

This is a prospective study involving male patients seen at the urology clinic of a Federal teaching hospital in southeast Nigeria between January 2016 and December 2018. Approval for the study was obtained from the ethical committee of the hospital and informed written consent from the individual patients.

\subsection{Exclusion Criteria}

1) Those with un-descended testis.

2) Patients with diabetes mellitus.

3) Those on treatment for any form of Hypogonadism. 
4) Those with intra-abdominal mass.

5) History of previous scrotal surgery/varicocelectomy.

A minimal sample size of 102 was calculated for the study. These 102 patients were seen at the urology clinic. 14 of them had one of the exclusion criteria. Eighty eight patients with inclusion criteria were recruited into the study.

The age, marital status, occupation and drug history of the individual patients were obtained and recorded in a proforma. Presenting complaints were documented. A physical examination was conducted on the patient. The varicocele was palpated both in the erect and supine positions. The varicoceles were confirmed using color flow Doppler US of the scrotum and the dimensions in millimeter $(\mathrm{mm})$ recorded. Blood samples of the patients were taken between $8 \mathrm{am}$ and $10 \mathrm{am}$ for serum levels of Follicular stimulating hormone (FSH), luteinizing hormone (LH), total testosterone (TT) and Prolactin (PRL) at recruitment time. The laboratory estimation of serum TT was by an Elisa Kit (AccuBind ${ }^{\circledR}$ Microwell ELISA Kit, Monobind Inc., Lake Forest, CA, USA) [2]. For the infertile men who had been on a stable sexual relationship for at least 12 months in addition had semen analysis. All the patients had a subinguinal microsurgical varicocelectomy and bilateral in those with bilateral varicoceles by the author. At 6 months post varicocele repair, blood samples were taken for TT, FSH, LH and PRL.

\subsection{Subinguinal Microsurgical Varicocelectomy}

Under spinal anesthesia an oblique 3 centimetres $(\mathrm{cm})$ incision (Figure 1) is made across the external ring and extended through Camper's and Scarpa's fascias. Retracting both sides of the incision using Langenberg retractors, the spermatic cord is grasped using Babcock forceps (Figure 2) delivered and placed over a sterile guaze. The microscope is brought into the operating field and the cord examined under 10 - 15 power magnification. I incise the external and internal spermatic fascias and examine the cord contents. The external spermatic fascia and associated structures (external spermatic vessels, vas deference and its vessels, cremasteric muscle and its vessels) are separated and secured. The internal spermatic fascia and contents are examined (Figure 3). Using subtle pulsation and $20 \mathrm{MHz}$ microvascular Doppler probe, the internal spermatic arteries are identified and preserved. The lymphatic vessels are preserved. I ligate the internal spermatic veins with silk $3 / 0$ and divide.

Contents of the external spermatic fascia are dissected. The vas deference and its artery are preserved, cremasteric artery and other arteries are preserved. The external spermatic veins are ligated with $3 / 0$ silk and divided. Remaining contents of the cord (vas deference and artery, cremasteric muscle and artery, internal spermatic/testicular arteries, lyhmphatic channels) are returned into the wound with a gentle pull on the ipsilateral hemiscrotum. Both Camper's and Scarpa's fascias are closed with 3/0 vicryl suture. The skin is closed with a running subcuticular $3 / 0$ vicryl suture and the wound dressed with a sterile gauze. 


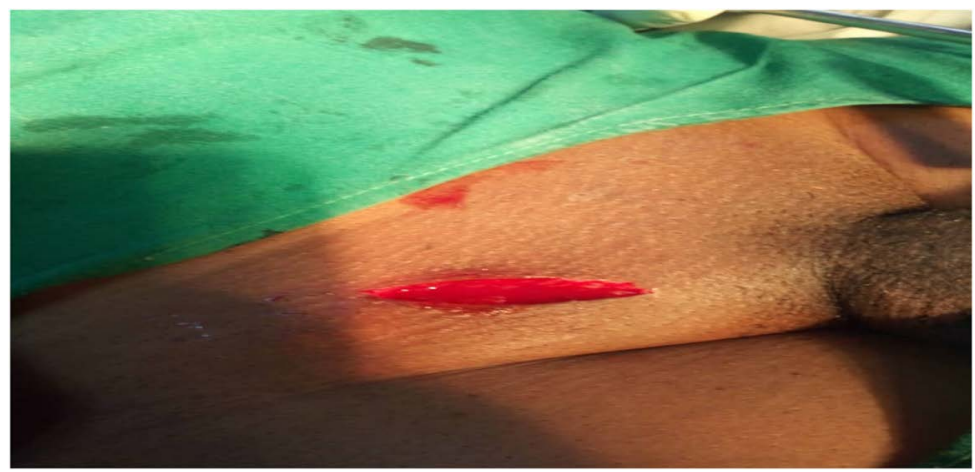

Figure 1. Skin incision.

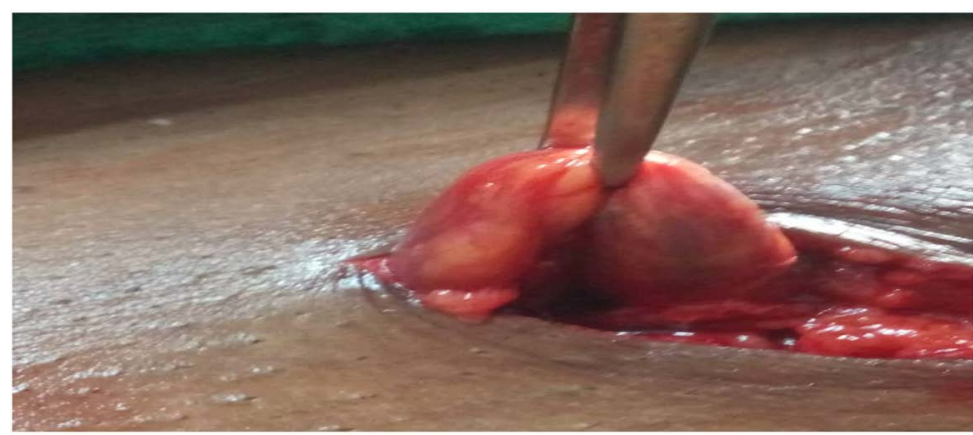

Figure 2. Spermatic cord grasped with babcock forceps.

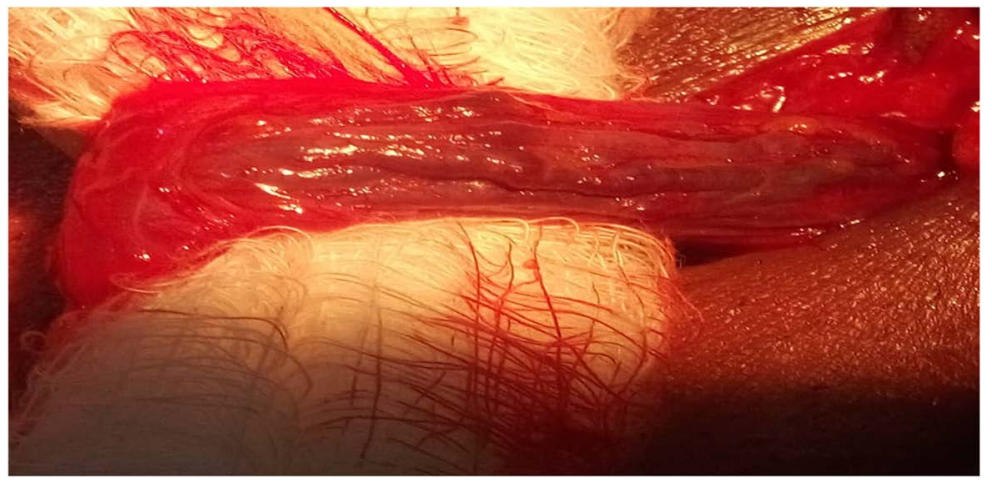

Figure 3. Internal spermatic fascia and contents.

\subsection{Statistical Analysis}

The data were analyzed using both descriptive and inferential statistics. The descriptive statistics, frequency, percent, mean and standard deviation were used to summarize the data. The inferential statistics, Mann-Whitney test was used to ascertain the effect of varicocelectomy on TT values at $5 \%$ level of significance. Kruskal-Wallis and ANOVA were used to compare different increases in TT in the varicocele grades and ages respectively. The unit of testosterone in this study is ng/dl. Significant effect hence existed if $\mathrm{P}$-value was less than $0.05(\mathrm{P}<0.05)$ otherwise no significance. These statistics were done with the aid of the statistical package for social sciences (SPSS v25 and Microsoft. The normal range of serum total testosterone level in the hospital of study is $300-1000 \mathrm{ng} / \mathrm{dl}$. 


\section{Results}

A total of 88 men who met the inclusion criteria were enrolled into the study. The age range was 19 - 58 years with a mean and standard deviation of $33.43 \pm$ 7.82 years. Most of the patients $60.2 \%$ were in the fourth decade of life and 52 (59.1\%) patients were married (Table 1 ). Presenting symptoms included, erectile dysfunction (ED) in 59 (67\%) patients, scrotal swelling in 48 (54.5\%) patients (Figure 4). 16 patients had scrotal pain pre varicocelectomy. Out of these in 15 (93.8\%) patients the pain resolved at 3 months post varicocelectomy. The remaining one patient was found to have a transverse left lying testis and intermittent torsion. He had orchiopexy and the pain stopped. Scrotal swelling resolved in all the 48 patients at 3 months post varicocelectomy. Out of the 59 (67\%) patients that had erectile dysfunction, 44 (75.58\%) patients had improvement in sexual function at 10 months post varicocelectomy. There was improvement in International index of erectile function (IIEF-5) scores from $16.2 \pm$ 3.6 to $20 \pm 1.8 \mathrm{P}<0.001$.

There was isolated left varicocele in 57 (64.8\%) patients (Table 1) and (Figure 5). Grade 1 varicocele was present in 19 (17.2\%) patients, 39 (35.5\%) patients

Table 1. Age of patients in years.

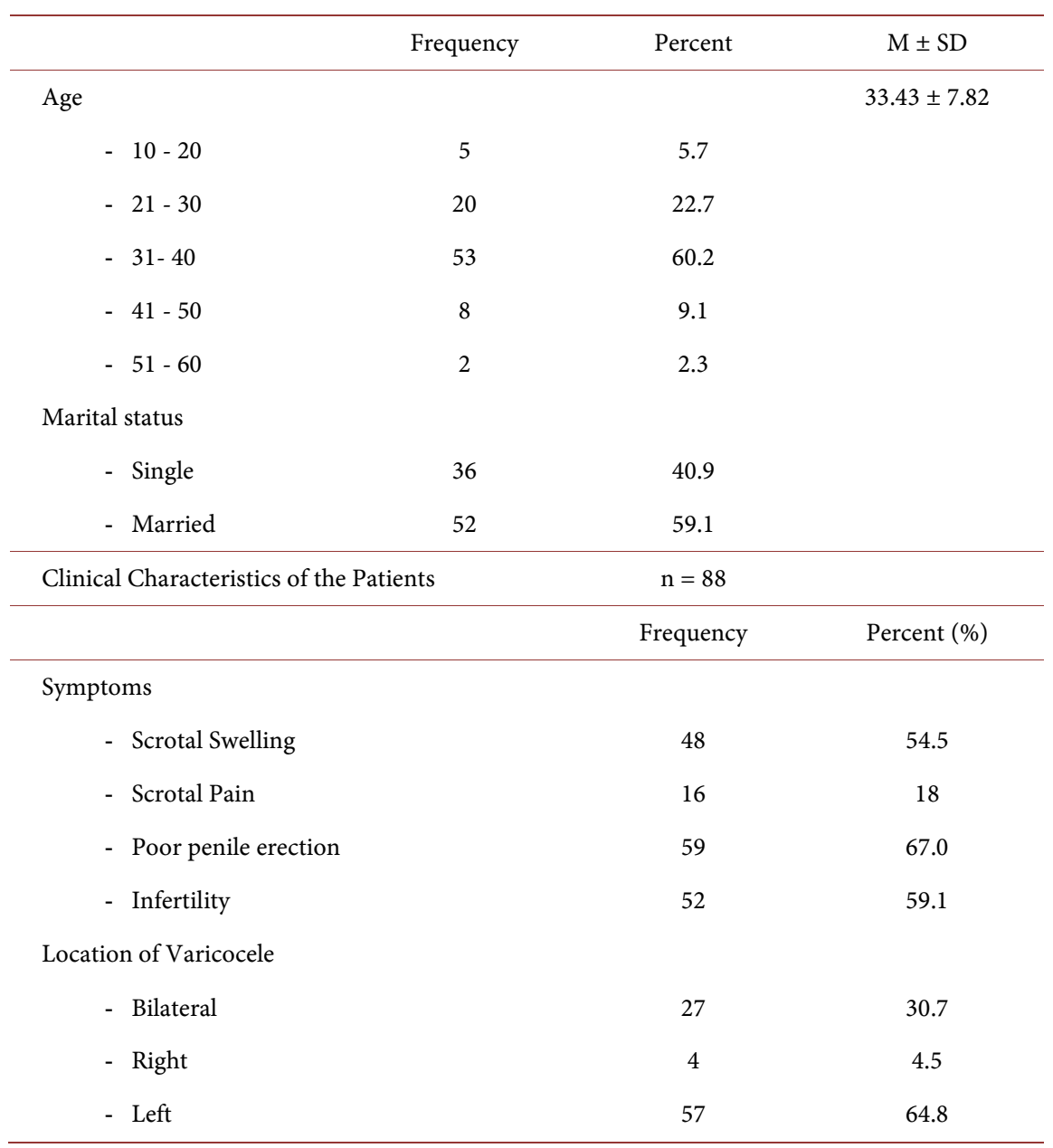




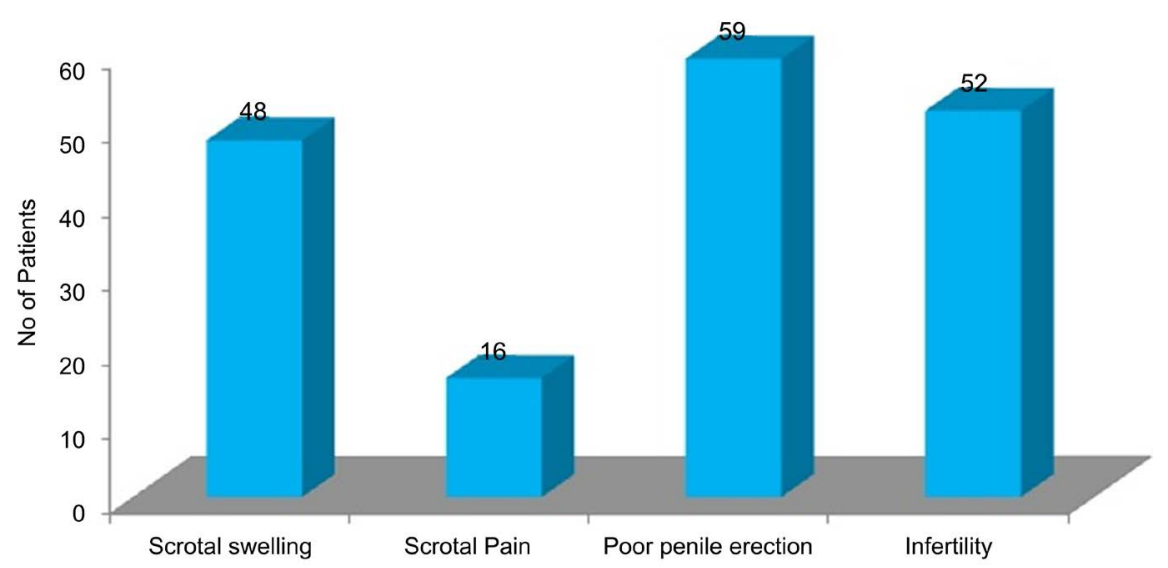

Figure 4. Symptoms experienced by the patients.

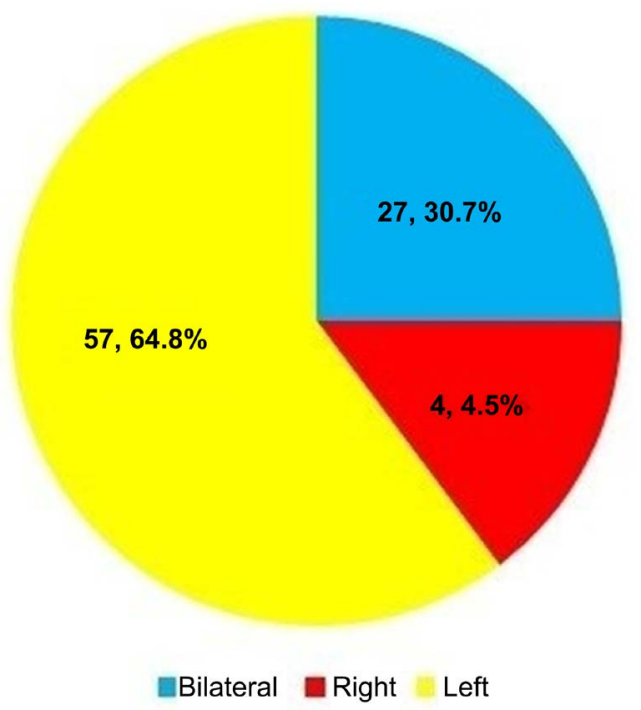

Figure 5. Location of varicocele.

had grade 2 varicocele while grade 3 varicocele was present in $52(47.3 \%)$ patients. Sixty five (59.1\%) varicoceles measured between $4.1-6.0 \mathrm{~mm}$ in diameter. The overall range was between $2.5-6.5 \mathrm{~mm}$ with mean and standard deviation of $4.2 \pm 0.78 \mathrm{~mm}$ (Table 2 ).

Pre-varicocelectomy, 61 (69.3\%) patients had testosterone values of between $100-291 \mathrm{ng} / \mathrm{dl}$. The range was between $80-490 \mathrm{ng} / \mathrm{dl}$ with a mean of $241 \pm 0.91$ ng/dl. Post-varicocelectomy, 56 (63.6\%) patients had serum TT values of 300 $490 \mathrm{ng} / \mathrm{dl}$. The range was $90-1500 \mathrm{ng} / \mathrm{dl}$ with mean of $482 \pm 2.87 \mathrm{ng} / \mathrm{dl}$. The mean serum TT levels increased from $241 \pm 0.91 \mathrm{ng} / \mathrm{dl}$ to post varicocele repair of $482 \pm 2.87 \mathrm{ng} / \mathrm{dl}(\mathrm{P}<0.001)$. The effect of varicocelectomy on serum TT levels was statistically significant (Table 3 and Table 4 ) and (Figure 6).

Fifty five (79\%) out of 70 patients that had $<300 \mathrm{ng} / \mathrm{dl}$ testosterone pre varicocelectomy normalized post varicocelectomy. There was mean increase of 260 $\mathrm{ng} / \mathrm{dl}$ to $395 \mathrm{ng} / \mathrm{dl} \mathrm{P}<0.0001$. The percentage increase for individual patients ranged from $52.2 \%, 69.7 \%, 78.8 \%$ to $110 \%$. The mean difference in the increase 
Table 2. Classification and dimension of varicoceles $(n=110)$.

\begin{tabular}{ccccc}
\hline & No. of Varicoceles & Percent (\%) & Range & M \pm SD \\
\hline Classification of Varicoceles & 19 & 17.2 & & \\
-1 & 39 & 35.5 & & \\
-2 & 52 & 47.3 & & \\
-3 & & & $2.5-6.5$ & $4.2 \pm 0.78$ \\
Dimensions of Varicoceles (mm) & 19 & 17.3 & & \\
$-2.5-3.0$ & 23 & 20.9 & & \\
$-3.1-4.0$ & 43 & 39.1 & & \\
$-4.1-5.0$ & 22 & 20.0 & & \\
$-5.1-6.0$ & 3 & 2.7 & & \\
$-6.1-7.0$ & &
\end{tabular}

Table 3. Testosterone values pre- and post-varicocelectomy $(n=88)$.

\begin{tabular}{lcc}
\hline Testosterone value (ng/dl) & Frequency & Percent \\
\hline Pre & 9 & 10.2 \\
$-<100$ & 61 & 69.3 \\
$-100-299$ & 18 & 20.5 \\
$-300-499$ & 0 & 0.0 \\
$-500-1000$ & 0 & 0.0 \\
$->1000$ & & \\
- Post & 2 & 2.3 \\
$-<100$ & 11 & 12.5 \\
$-100-299$ & 56 & 63.6 \\
$-300-499$ & 17 & 19.3 \\
$-500-1000$ & 2 & 2.3 \\
\hline
\end{tabular}

Table 4. Effect of varicocelectomy on testosterone.

\begin{tabular}{cccccc}
\hline \multicolumn{5}{c}{ Testosterone Value (ng/dl) } & p-value \\
\hline & Range & $\mathrm{M} \pm \mathrm{SD}$ & $95 \%$ C.I & Mean Rank & \\
\hline Varicocelectomy & & & & 320.0 & $<0.001$ \\
- Pre & $80-490$ & $2.41 \pm 0.91$ & $1.19-1.58$ & 48.14 & \\
- Post & $90-1500$ & $4.82 \pm 2.87$ & $5.93-7.15$ & 128.86 \\
\hline
\end{tabular}

in levels of TT after varicocelectomy for grades I, II and III varicoceles were 201 $\pm 0.08,205 \pm 0.04,202 \pm 0.06 \mathrm{ng} / \mathrm{dl}$ respectively. Using Kruskal-Wallis to compare these mean respective increases of TT for grades I, II, and III gave the p-value of 0.951 , there is no statistical difference in the increasing levels of TT in 


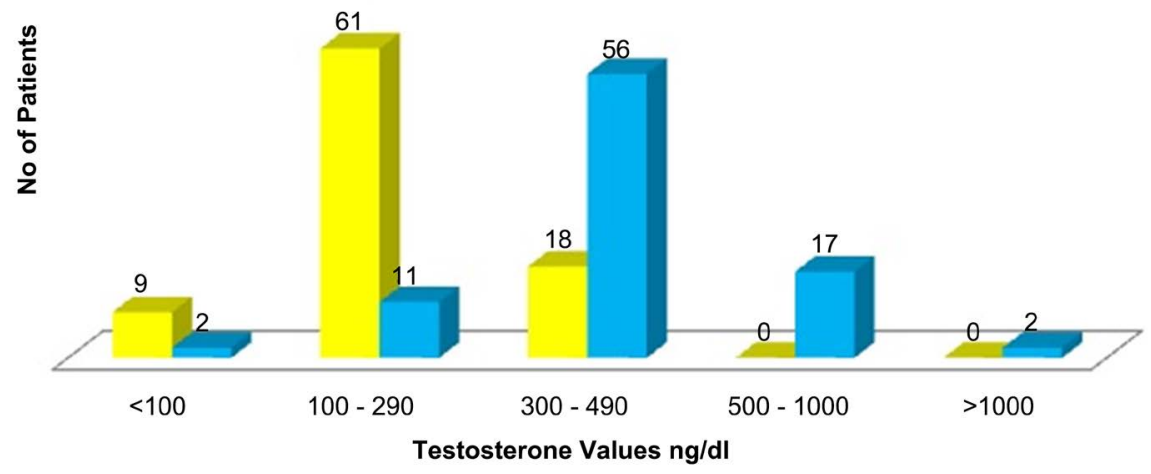

Figure 6. Testosterone values in ng/dl pre- and post-varicocelectomy.

grades I, II and III varicoceles. TT improvement post varicocelectomy is independent of varicocele grade in this study (See Table 5(a)).

Furthermore, analysis into the impact of age on total testosterone improvement post varicocelectomy shows that mean increase in TT for age groupings, less than 30 years, 31 - 40 years and above 40 years were $190 \pm 0.33,169 \pm 0.22$ and $153 \pm 0.28 \mathrm{ng} / \mathrm{dl}$ respectively. Using ANOVA to compare these respective mean increases gave a p-value of 0.238 . This implies there is no statistical difference between the TT mean increments in the three age groupings. Hence age did not have any impact on TT improvement after varicocelectomy in this study. There is post varicocelectomy improvement in TT at all ages (See Table 5(b)).

\section{Discussion}

It has been shown that men with clinical varicoceles have lower testosterone levels irrespective of age, with emerging evidence of beneficial effect of varicocelectomy on increases of serum TT regardless of patient's age or laterality of varicocele [15] [16]. The average age of patients in this series was $33.43 \pm 7.82$ years. In a similar but retrospective study by Tanrikut et al. in 2007, the average age of patients was $36 \pm 8$ years [17]. The incidence of scrotal pain in this study was $18 \%$. In other studies, $10 \%$ of varicoceles will present with scrotal pain [3] [4]. The higher prevalence in this study could be due to late presentation with worsening pathophysiology. Left sided varicocele was noted in $95.5 \%$ of the patients in this series. A prevalence of $85 \%-90 \%$ was reported by Leslie et al. [1] and by Gat et al. [18]. Furthermore bilateral varicocele was found in $30.7 \%$ of the patients and this was by physical palpation and color Doppler US of the scrotum. Alsaikhan et al. noted that $50 \%$ of men had bilateral varicocele [19]. Gat et al. using venography in his series found bilateral varicocele in $80.8 \%$ of his patients [18].

In this series the pre-varicocelectomy mean TT was $241 \pm 0.91 \mathrm{ng} / \mathrm{dl}$. Several mechanisms have been proposed to explain the deleterious effect of varicocele on leydig cell function. These include scrotal hyperthermia, reflux of adrenal and 
Table 5. (a) Comparing mean total testosterone levels pre- and post-varicocelectomy based on varicocele grading; (b) Comparing mean total testosterone levels pre- and postvaricocelectomy based on age.

(a)

\begin{tabular}{cccccc}
\hline & Grade & Pre-Repair & Post-Repair & $\mathrm{Z}$ & P-value \\
\hline TT ng/dl & 1 & $297 \pm 0.01$ & $498 \pm 0.09$ & -2.810 & 0.005 \\
& 2 & $234 \pm 0.24$ & $439 \pm 0.28$ & -2.805 & 0.005 \\
& 3 & $210 \pm 0.05$ & $412 \pm 0.11$ & -2.812 & 0.005 \\
\hline
\end{tabular}

(b)

\begin{tabular}{cccccc}
\hline & Age & Pre-Repair & Post-Repair & Z & P-value \\
\hline TT ng/dl & $<30$ yrs & $298 \pm 0.15$ & $488 \pm 0.48$ & -2.524 & 0.012 \\
& $31-40$ yrs & $278 \pm 0.47$ & $447 \pm 0.69$ & -2.51 & 0.012 \\
& $>40$ yrs & $282 \pm 0.42$ & $435 \pm 0.70$ & -2.521 & 0.012
\end{tabular}

renal metabolites and increased hydrostatic pressure in the internal spermatic vein [14] [19] [20]. Furthermore there is increased exposure of the testis to gonadotoxins from suboptimal drainage due to venous dilatation [21], varicocele induced increase in reactive oxygen species production and testicular hypoperfusion [6] [14] [19] [20]. Leydig cells are the principal androgen producing cells producing up to $95 \%$ of TT in men [6] [14]. Patients with clinical varicocele have leydig cell atrophy, leydig cell structural changes and marked decrease in quantity of testosterone positive leydig cells [20]. Testosterone production in leydig cell is a 5 -stage enzymatic process that leads to conversion of 17-hydroxyprogesterone to testosterone by the enzyme 17 alpha-hydroxyprogesterone aldolase. The most accepted hypothesis that explains the effect of varicocele on leydig cell function hinges on changes on the testicular thermal environment. The testicular veins leaving the testis form a communicating meshwork of veins that produce a counter-current heat exchange mechanism to cool the arterial blood flowing into the testis [22]. This cooling mechanism is lost in patients with clinical varicocele causing elevated scrotal temperatures by $2.6^{\circ} \mathrm{C}$ due to regurgitation of warm abdominal blood through incompetent valves [23] [24] [25]. Thus the scrotal hyperthermia affects adversely this enzyme that produces testosterone [6] [14] [19] [20]. As noted in this study, 69.3\% of the patients had serum TT of between $100-299 \mathrm{ng} / \mathrm{dl}$ pre varicocelectomy. Other studies have shown that varicocele adversely affects leydig cell function leading to low serum TT [26] [27] [28]. Furthermore varicocele increases apoptosis in leydig cells and suppresses the expression of the StAR protein [27]. Six months post varicocelectomy, 63.6\% of the patients had serum TT levels of between $300-490 \mathrm{ng} / \mathrm{dl}$. The mean serum TT rose to $482 \pm 2.87 \mathrm{ng} / \mathrm{dl}(\mathrm{P}<0.001)$. Subinguinal microsurgical varicocelectomy robustly and significantly raised the serum TT of patients in this series. Other researchers have produced similar results in their respective studies [2] [22] [29] [30] [31] [32]. Furthermore $60 \%-80 \%$ of men with low serum testosterone will exhibit normalization of testosterone levels after varicocele repair [33]. In this series, 55 (79\%) patients exhibited normalization of testosterone le- 
vels after repair.

Sathya Srini et al. studied 200 infertile men with varicocele who had serum TT of $280 \mathrm{ng} / \mathrm{dl}$. One hundred men underwent surgical repair and had increase in TT from $177.2 \pm 18.44$ to $301 \pm 43 \mathrm{ng} / \mathrm{dl}(\mathrm{P}<0.001)$ at six months post-operatively [30].

Zohdy et al. carried out microsurgical varicocelectomy in 103 men with clinical varicocele and the TT levels increased significantly from $379.1 \pm 205.8$ to $450.1 \pm 170.2 \mathrm{ng} / \mathrm{dl}(\mathrm{P}<0.0001)$ at 6 months post-operatively [31].

Hsiao et al. retrospectively reviewed 78 men. They had subinguinal microsurgical varicocelectomy. At 7 months post-operatively, there was a statistically significant increase in TT from $308.4 \pm 7.1 \mathrm{ng} / \mathrm{dl}$ to $417.5 \pm 14.8 \mathrm{ng} / \mathrm{dl}(\mathrm{P}<0.0001)$ [32].

Nineteen $(17.2 \%)$ out of the 110 varicoceles were grade 1 varicoceles and were part of the bilateral varicoceles. These 19 varicoceles were repaired subinguinally. A left varicocele produces blood column of 40 centimeters $(\mathrm{cm})$, and this high hydrostatic pressure is exerted on the pampiniform plexus [34]. When this high venous pressure exceeds the arteriolar pressure in the testicular microcirculatory system, the hypoxic effect occurs bilaterally [34]. It must be stated that both palpable and non-palpable veins have the same adverse effects on the testis and so varicocelectomy on the left ignoring bypasses is not adequate to correct the problem [34]. Thus bilateral varicocele repair was done in these patients to reverse bilateral testicular dysfunction and improve testosterone production.

In stratifying the TT improvement after subinguinal varicocelectomy based on varicocele grade, it was found that varicocele grade had no impact on Serum TT improvement after varicocele repair. Other studies have noted similar findings [32] [33]. Furthermore, stratification of the patients into various age groupings showed that testosterone improvement occurred across all age groupings. Age did not impact the TT improvement after varicocele repair as TT improvement was noted in older age groups in another study [35].

The limitations of the study are low awareness of varicocele within the population of study and thus decrease flow of patients with clinical varicoceles to the urology clinic. Lack of previous research work on the topic from this part of the world thus paucity of local data to work with. Hormonal assays are expensive and posed economic stress on the researcher.

\section{Conclusion}

The results from this study support the observation that subinguinal microsurgical varicocelectomy robustly increases the serum levels of TT. This will reverse the adverse effects of low testosterone in patients.

\section{Acknowledgements}

I thank Mr. Stanley Ndoh for his technical assistance. I remain grateful to the resident doctors in urology during the period of study for assistance in data col- 
lection.

\section{Permission}

The ethical committee of the hospital gave permission for this study to be carried out.

\section{Conflicts of Interest}

The author declares no conflicts of interest regarding the publication of this paper.

\section{References}

[1] Leslie, S.W., Sajjad, H. and Siref, L.E. (2019) Varicocele. Statpearls Publishing, Treasure Island.

[2] Jangkhah, M., Farrahi, F., Sadighi-Gilani, M.A., Hosseini, S.J., Dadkhah, F., Salmanyazdi, R., et al. (2018) Effects of Varicocelectomy on Serum Testosterone Levels among Infertile Men with Varicocele. International Journal of Fertility and Sterility, $12,169-172$.

[3] Owen, R.C., McCormic, B.J., Figler, B.D. and Coward, R.M. (2017) A Review of Varicocele Repair for Pain. Translational Andrology and Urology, 6, S20-S29. https://doi.org/10.21037/tau.2017.03.36

[4] Lundy, S.D. and Sabanegh, E.S. (2017) Varicocele Management for Infertility and Pain: A Systematic Review. Arab Journal of Urology, 16, 157-170. https://doi.org/10.1016/j.aju.2017.11.003

[5] Asafu-Adgei, D., Judge, C., Deibert, C.M., Li, G., Stember, D. and Stahl, P.J. (2020) Systemic Review of the Impact of Varicocele Grade on Response to Surgical Management. The Journal of Urology, 203, 48-56. https://doi.org/10.1097/JU.0000000000000311

[6] Clavijo, R.I., Carrasquillo, R. and Ramasamy, R. (2017) Varicoceles: Prevalence and Pathogenesis in Adult Men. Fertility and Sterility, 108, 364-369.

https://doi.org/10.1016/j.fertnstert.2017.06.036

[7] Afshar, K. and Domes, T. (2018) Varicocele. Canadian Urological Association Journal, 12, S34-S36. https://doi.org/10.5489/cuaj.5231

[8] Rahman, K.U., Zameb, H., Qureshi, A.B., Yousaf, M.S., Numan, A., MAjeed, K.A., et al. (2019) Correlation between Testicular Hemodynamic and Semen Quality Indices Clinical Varicocele Patients in Pakistan. BioMed Research International, 2019, Article ID: 7934328. https://doi.org/10.1155/2019/7934328

[9] Jensen, C.F.S., Ostergren, P., Dupree, I.M., Ohi, D.A., Senksen, J. and Fode, M. (2017) Varicocele and Male Infertility. Nature Reviews Urology, 14, 523-533. https://doi.org/10.1038/nrurol.2017.98

[10] Cho, C.L., Esteves, S.C. and Agarwal, A. (2016) Novel Insights into the Pathophysiology of Varicocele and Its Association with Reactive Oxygen Species and Sperm DNA Fragmentation. Asian Journal of Andrology, 18, 186-193. https://doi.org/10.4103/1008-682X.170441

[11] Tsili, A.C., Xiropotamou, O.N., Sylakos, A., Maliakas, V., Sofikitis, N. and Argyropoulou, M. (2017) Potential Role of Imaging in Assessing Harmful Effects on Spermatogenesis in Adult Testis with Varicocele. World Journal of Radiology, 9, 34-45. https://doi.org/10.4329/wjr.v9.i2.34 
[12] Shridharani, A., Owen, R.C., Elkelany, O.O. and Kim, E.D. (2016) The Significance of Clinical Practice Guidelines on Adult Varicocele Detection and Management. Asian Journal of Andrology, 18, 269-275. https://doi.org/10.4103/1008-682X.172641

[13] Dubin, L. and Amelar, R.D. (1970) Varicocele Size and Results of Varicocelectomy in Selected Subfertile Men with Varicocele. Fertility and Sterility, 21, 606-709. https://doi.org/10.1016/S0015-0282(16)37684-1

[14] Fisch, H. and Hyun, G. (2017) Varicocele Repair for Low Testosterone. Current Opinion in Urology, 22, 495-498. https://doi.org/10.1097/MOU.0b013e328358e0fb

[15] Mehta, A. and Goldstein, M. (2013) Microsurgical Varicocelectomy: A Review. Asian Journal of Andrology, 15, 56-60. https://doi.org/10.1038/aja.2012.98

[16] Bach, P.V., Najari, B.B. and Goldstein, M. (2016) Varicocele, a Case for Early Intervention [Version 1; Peer Review: 3 Approved]. F1000 Research, 8, 670. https://doi.org/10.12688/f1000research.7179.1

[17] Tarinkut, C., Choi, J.M., Rosof, J.S., Nelson, C.J., Mulhall, J.P. and Goldstein, M. (2007) Improvement in Serum Testosterone Levels after Varicocelectomy. Fertility and Sterility, 88, S386. https://doi.org/10.1016/j.fertnstert.2007.07.1282

[18] Gat, Y., Bachar, G.N., Zukerman, Z., Belenky, A. and Gornich, M. (2004) Varicocele: A Bilateral Disease. Fertility and Sterility, 8, 424-429.

https://doi.org/10.1016/j.fertnstert.2003.08.010

[19] Alsaikhan, B., Alrabeeah, K., Delouya, G. and Zini, A. (2016) Epidemiology of Varicocele. Asian Journal of Andrology, 18, 179-181.

https://doi.org/10.4103/1008-682X.172640

[20] Dobaja, A.A. and Goldstein, M. (2016) When Is Varicocele Repair Indicated: The Dilemma of Hypogonadism and Erectile Dysfunction? Asian Journal of Andrology, 18, 213-216. https://doi.org/10.4103/1008-682X.169560

[21] Pastuszak, A.W. and Wang, R. (2015) Varicocele and Testicular Function. Asian Journal of Andrology, 17, 659-667. https://doi.org/10.4103/1008-682X.153539

[22] Li, F., Yua, H., Yamaguchi, K., Okada, K., Matsushita, K., Ando, M., et al. (2012) Effect of Surgical Repair on Testosterone Production on Infertile Men with Varicocele: A Meta Analysis. International Journal of Urology, 19, 149-154. https://doi.org/10.1111/j.1442-2042.2011.02890.x

[23] Durairajanayagam, D., Agarwal, A. and Ong, C. (2015) Causes, Effects and Molecular Mechanisms of Testicular Heat Stress. Reproductive Biomedicine Online, 30, 14-27. https://doi.org/10.1016/j.rbmo.2014.09.018

[24] Hassanin, A.M., Ahmed, H.H. and Kaddeh, A.N. (2018) A Global View of the Pathophysiology of Varicocele. Andrology, 6, 654-661.

https://doi.org/10.1111/andr.12511

[25] Garrolla, A., Torino, M., Micla, P., Carreta, N., Pizzol, D., Menegazzo, M., et al. (2015) Twenty Four Hour Monitoring of Scrotal Temperature in Obese Men and Men with a Varicocele as a Mirror of Spermatogenic Function. Human Reproduction, 30, 1006-1013. https://doi.org/10.1093/humrep/dev057

[26] Hrtado de Catalfo, G.E., Ranieri Cassila, A., Maro, F.A., de Aaniz, M.J. and Marra, C.A. (2007) Oxidative Stress Biomarkers and Hormonal Profile in Human Patients Undergoing Varicocelectomy. International Journal of Andrology, 30, 519-530. https://doi.org/10.1111/j.1365-2605.2007.00753.x

[27] Tanrikut, C., McQuaid, J.W. and Goldstein, M. (2011) The Impact of Varicocele and Varicocele Repair on Serum Testosterone. Current Opinion in Obstetrics and Gynecology, 23, 227-231. https://doi.org/10.1097/GCO.0b013e328348a3e2 
[28] Elzanaty, S. and Johansen, C. (2007) Microsurgical Subinguinal Varicocele Repair of Grade II-III Lesions Associated with Improvements of Testosterone Levels. Current Urology, 10, 45-49. https://doi.org/10.1159/000447150

[29] Almahdy, A.M., Gamal Eldn, A.A., Abdullah, M.M. and Abuzzaid, M.I. (2014) Varicocele Repair Outcome with Respect to Hormomal Profile and Spermogram Pattern. Menoufia Medical Journal, 27, 164-168. https://doi.org/10.4103/1110-2098.132792

[30] Sathya Srini, V. and Belur Veerachari, S. (2011) Does Varicocelectomy Improve Gonadal Function in Men with Hypogonadism and Infertility. Analysis of a Prospective Study. International Journal of Endocrinology, 2011, Article ID: 916380. https://doi.org/10.1155/2011/916380

[31] Zohdy, W., Ghazi, S. and Arafa, M. (2011) Impact of Varicocelectomy on Gonadal and Erectile Functions in Men with Hypogonadism and Infertility. The Journal of Sexual Medicine, 8, 885-893. https://doi.org/10.1111/j.1743-6109.2010.01974.x

[32] Hsiao, W., Rosoff, J.S., Pale, J.R., Powell, J.L. and Goldstein, M. (2013) Varicocelectomy Is Associated with Increases in Serum Testosterone Independent of Clinical Grade. Urology, 81, 1213-1217. https://doi.org/10.1016/j.urology.2013.01.060

[33] Cayan, S., Akbay, E., Saylam, B. and Kadioglu, A. (2020) Effect of Varicocele and Its Treatment on Testosterone in Hypogonadal Men with Varicocele: Review of the Literature. Balkan Medical Journal, 37, 121-124. https://doi.org/10.4274/balkanmedj.galenos.2020.2020.1.85

[34] Gat, Y., Zukerman, Z., Chakraborty, J. and Gornish, M. (2005) Varicocele, Hypoxia and Male Infertility. Fluid Mechanics, Analysis of the Impaired Testicular Venous Drainage System. Human Reproduction, 20, 2614-2619.

https://doi.org/10.1093/humrep/dei089

[35] Resorlu, B., Kara, C., Sahin, E. and Unsal, A. (2010) The Significance of Age on Success of Surgery for Patients with Varicocele. International Urology and Nephrology, 42, 351-356. https://doi.org/10.1007/s11255-009-9589-y 